
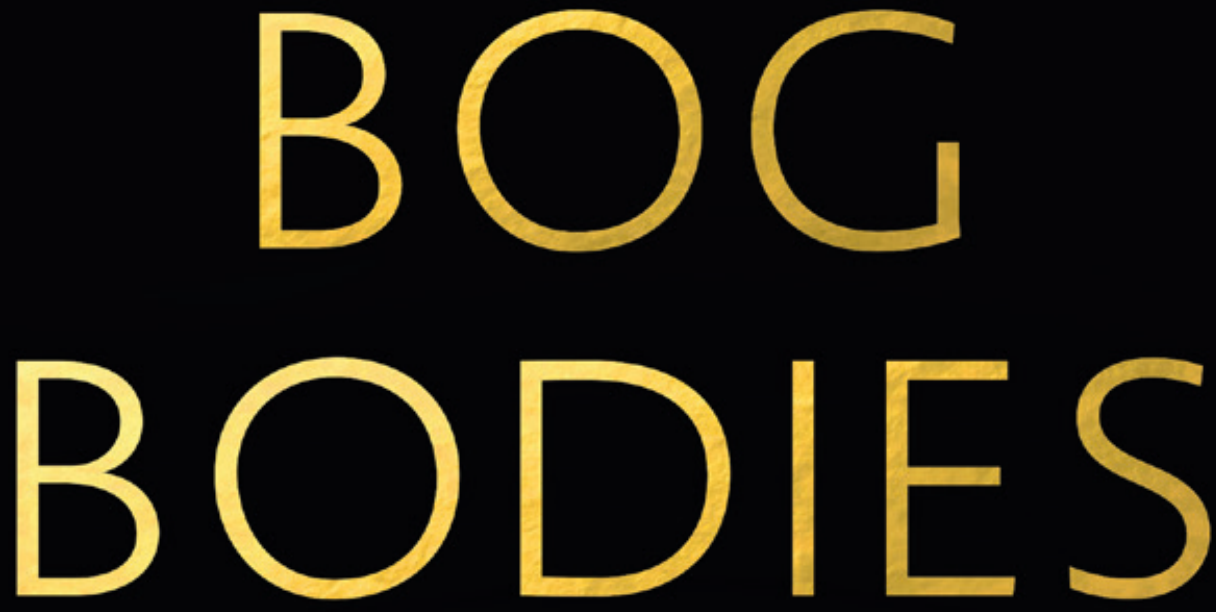

FACE TO FACE WITH THE PAST

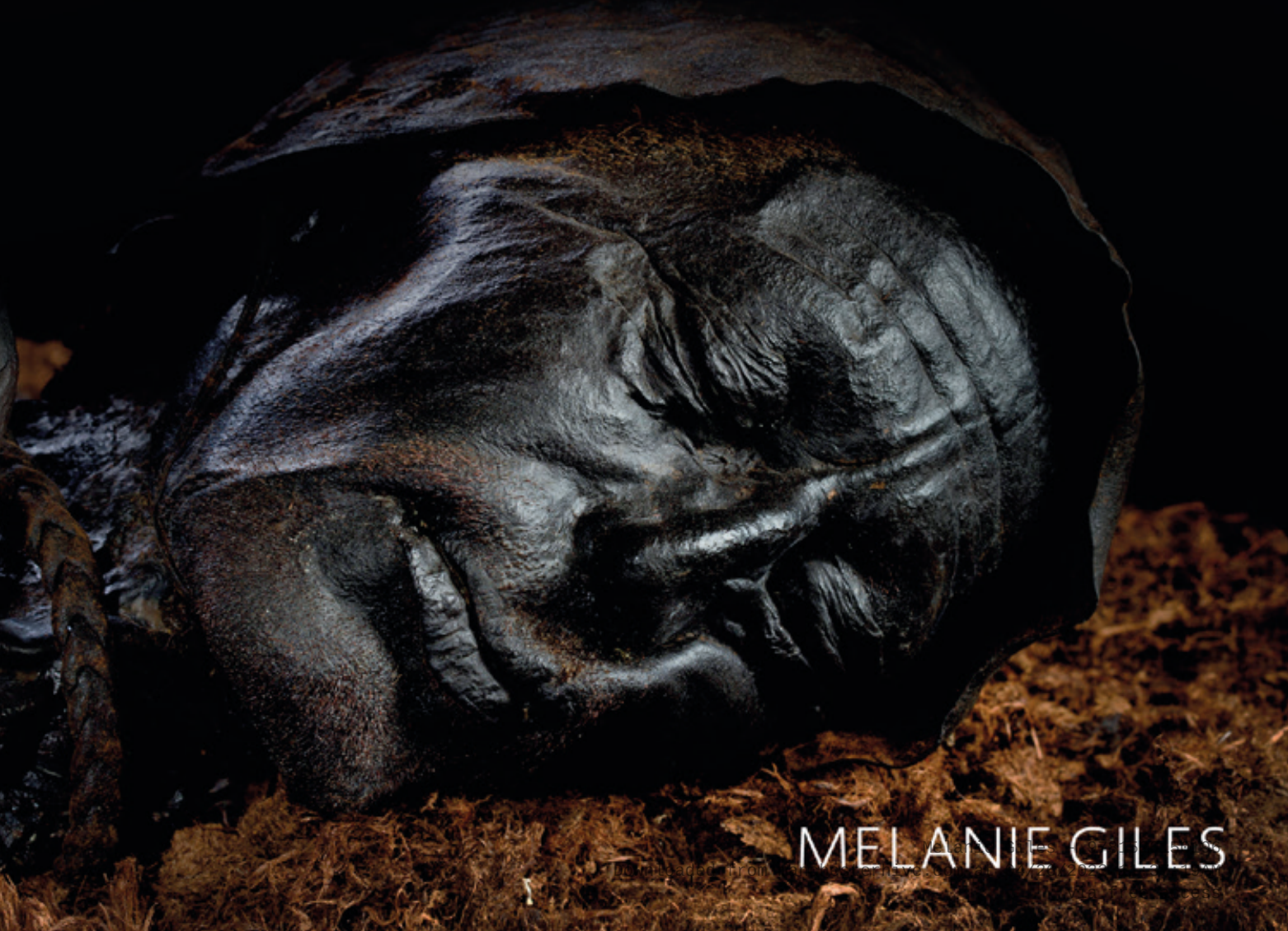




\section{Bog bodies}

\section{MANCHESTER

Manchester University Press 
Melanie Giles - 9781526150196 Downloaded from manchesterhive.com at $04 / 26 / 2023$ 11:37:19AM via free access 


\section{Bog bodies}

Face to face with the past

\section{MELANIE GILES}

Manchester University Press 
The right of Melanie Giles to be identified as the author of this work has been asserted by her in accordance with the Copyright, Designs and Patents Act 1988.

This electronic version has been made available under a Creative Commons (CC-BY - NCND) licence, thanks to the support of University of Manchester Library, which permits non-commercial use, distribution and reproduction provided the author(s) and

Manchester University Press are fully cited and no modifications or adaptations are made. Details of the licence can be viewed at https://creativecommons.org/licenses/by-nc-nd/4.0/

Published by Manchester University Press

Altrincham Street, Manchester M1 7JA

www.manchesteruniversitypress.co.uk

British Library Cataloguing-in-Publication Data

A catalogue record for this book is available from the British Library

ISBN 9781526150189 paperback

First published 2020

The publisher has no responsibility for the persistence or accuracy of URLs for any external or third-party internet websites referred to in this book, and does not guarantee that any content on such websites is, or will remain, accurate or appropriate.

Cover image: Tollund Man @ Museum Silkeborg

Typeset by Newgen Publishing UK 